Article

\title{
In Vitro Study of Two Edible Polygonoideae Plants: Phenolic Profile, Cytotoxicity, and Modulation of Keap1-Nrf2 Gene Expression
}

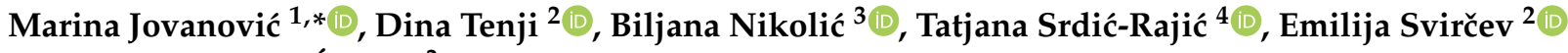 \\ and Dragana Mitić-Ćulafić ${ }^{3}$ \\ 1 Institute of General and Physical Chemistry, Studentski trg 12-14/V, 11000 Belgrade, Serbia \\ 2 Faculty of Sciences, University of Novi Sad, Trg Dositeja Obradovića 3, 21000 Novi Sad, Serbia; \\ dinatenji@gmail.com (D.T.); emilija.svircev@dh.uns.ac.rs (E.S.) \\ 3 Faculty of Biology, University of Belgrade, Studentski trg 16, 11000 Belgrade, Serbia; \\ biljanan@bio.bg.ac.rs (B.N.); mdragana@bio.bg.ac.rs (D.M.-Ć.) \\ 4 Institute of Oncology and Radiology of Serbia, Pasterova 14, 11000 Belgrade, Serbia; tsrdic@gmail.com \\ * Correspondence: marina.rajic.jovanovic@gmail.com; Tel.: +381-63-74-43-004
}

\section{check for}

updates

Citation: Jovanović, M.; Tenji, D.; Nikolić, B.; Srdić-Rajić, T.; Svirčev, E.; Mitić-Ćulafić, D. In Vitro Study of Two Edible Polygonoideae Plants: Phenolic Profile, Cytotoxicity, and Modulation of Keap1-Nrf2 Gene Expression. Foods 2021, 10, 811. https://doi.org/10.3390/foods10040811

\section{Academic Editors:}

Francisca Rodrigues and

Verica Dragović-Uzelac

Received: 26 February 2021

Accepted: 7 April 2021

Published: 9 April 2021

Publisher's Note: MDPI stays neutral with regard to jurisdictional claims in published maps and institutional affiliations.

Copyright: (c) 2021 by the authors. Licensee MDPI, Basel, Switzerland. This article is an open access article distributed under the terms and conditions of the Creative Commons Attribution (CC BY) license (https:// creativecommons.org/licenses/by/ $4.0 /)$.

\begin{abstract}
Polygonum aviculare and Persicaria amphibia (subfam. Polygonoideae) are used in traditional cuisines and folk medicine in various cultures. Previous studies indicated that phytochemicals obtained from Polygonoideae plants could sensitize chemoresistant cancer cells and enhance the efficacy of some cytostatics. Here, the cytotoxic properties of chemically characterized ethanol extracts obtained from P. aviculare and P. amphibia, individually and in combination with doxorubicin (D), were determined against hepatocarcinoma HepG2 cells. Phenolic composition, cell viability, cell cycle, apoptosis, and the expression of Keap1 and Nrf2 were examined by following methods: LC-MS/MS, LC-DAD-MS, MTT, flow cytometry, and qRT-PCR. Extracts were rich in dietary polyphenolics. Synergistic cytotoxicity was detected for extracts combined with D. The observed synergisms are linked to the interference with apoptosis, cell cycle, and expression of Keap1-Nrf2 genes involved in cytoprotection. The combined approach of extracts and D could emerge as a potential pathway of chemotherapy improvement.
\end{abstract}

Keywords: edible plants; Polygonoideae; phenolic profile; doxorubicin; apoptosis; cell cycle; Keap1Nrf2 expression

\section{Introduction}

Widespread throughout Europe, Asia and the Americas, wild plants Polygonum aviculare and Persicaria amphibia (syn. Polygonum amphibium), subfamily Polygonoideae, are used in traditional cuisines and folk medicine in various cultures [1,2]. P. aviculare, known as the common knotweed, is edible and used as a Korean salad plant, an Australian honey plant, and a traditional Vietnam culinary herb [3-5]. In the USA, P. amphibia, popularly known as water smart weed, has been utilized in soft drink preparation [2]. Described as healing weeds, these plants are widely used as a home remedy to treat ailments such as stomach pains and diarrhea $[1,2,6,7]$. Concerning Serbia, $P$. aviculare is mainly used as an appetite stimulant [8]. Importantly, in the folk medicine of China and Austria P. aviculare and P. amphibia are employed to treat some types of cancer $[9,10]$. Chemical properties of these plants have been thoroughly investigated in recent decades and acquired data showed that their extracts are rich in flavonoids, sesquiterpenoids, and tannins, thus, justifying their ethnopharmacological use and contributing to their recognition in contemporary pharmacology $[1,2,11,12]$. Although a limited number of pharmacological studies regarding these herbs are available, some of them indicate that these plants and their active compounds could be used for the treatment of various diseases in clinical medicine, including diabetes 
and some types of cancer [13-15]. Furthermore, epidemiological evidence has demonstrated that a diet rich in natural bioactive compounds could decrease the risk of cancer development and could be used in chemoprevention. The discovery of plant-derived drugs has emerged as a potential pathway in the search for chemotherapeutics owing to the accepted assumption that plant medicaments are safer than their synthetic counterparts. In addition, toxic and other unfavorable effects of synthetic anticancer drugs have been widely noted $[2,16,17]$. Chemotherapy treatment with anthracycline drugs, such as doxorubicin (D), results in high hepatotoxicity. Apart from the numerous side effects, the medical application of $\mathrm{D}$ is also limited due to the frequent development of resistance in tumor cells $[18,19]$. Considering that D could rely on an increase in the free radical production to exhibit its effect, the reduction of antioxidant defense could initially make the cancerous cells susceptible to chemotherapeutics [20,21]. Importantly, numerous cancerous cells possess increased endogenous antioxidant defense due to the constitutive overexpression of the nuclear factor erythroid 2-related factor 2 (Nrf2) related to the disruption of Kelchlike ECH-associated protein 1 (Keap1) [19,22]. Keap1 acts as a negative regulator of Nrf2, and hence, it may act as a tumor suppressor in cancer cells. Nrf2 is the redox-sensitive transcription activator that regulates the expression of a large number of cytoprotective enzymes [23]. Thereby, Nrf2 has been proposed as a novel therapeutic target to overcome chemoresistance in various types of cancer, including hepatocellular carcinoma (HCC) [22] Moreover, it has been observed that some phytochemicals have the potential to sensitize chemoresistant HCC through the suppression of Nrf2 [22].

Therefore, in this work, the phenolic profiles and cytotoxic properties of ethanol extracts of aerial parts of $P$. aviculare (POA) and $P$. amphibia (PEA) were explored, as well as their potential to modulate the response of human hepatocellular carcinoma cells (HepG2) to D, the most widely used cytostatic in HCC treatment [16]. The cytotoxic properties of extracts, alone and combined with D, were estimated by MTT assay and flow cytometric analysis. The potential of co-treatments of extracts and D to influence Nrf2 and Keap1 expression was assessed by qRT-PCR. Thus, this study, in a comprehensive manner, investigated cytotoxic properties of POA and PEA. Using both plant extracts and cytostatic $\mathrm{D}$, it aimed to present the benefits of the combined approach in order to make an initial step in chemotherapy improvement.

\section{Materials and Methods}

\subsection{Materials}

Reference standards of the secondary metabolites used in LC-MS/MS analysis were obtained from Sigma-Aldrich Chem (Steinheim, Germany): 4-hydroxy-benzoic acid, 2,5dihydroxybenzoic acid, vanillic acid, gallic acid, cinnamic acid, caffeic acid, trans-ferulic acid, 3,4-dimethoxycinnamic acid, D-(-)-quinic acid, umbelliferon, matairesinol, secoisolariciresinol, chlorogenic acid, predominantly trans, quercetin dihydrat, (+)-catechin hydrate, baicalein, genistein, daidzein, baicalin, syringic acid, p-coumaric acid (predominantly trans isomer), 2-hydroxycinnamic acid (predominantly trans), sinapic acid (predominantly trans isomer), scopoletin, (-)-epicatechin, quercetin-3-O-beta-D-glucoside, quercitrin-hydrate, (-)-epigallocatechin gallate; Roth/Carl Roth $\mathrm{GmbH} /$ Rotichrom ${ }^{\circledR}$ : protocatechuic acid, esculetin, apigenin, apigenin-7-O-glucoside, hyperoside, chrysoeriol, amentoflavone trihydrate, apiin; Chromadex (Santa Ana, CA, USA): kaempherol, kaempferol 3-O-glucoside, naringenin, isorhamnetin; Extrasynthese Genay Cedex France: luteolin, luteolin-7-Oglucoside, and from Fluka Chemie GmbH (Buchs, Switzerland): myricetin, vitexin, rutin, trihydrate. HPLC gradient-grade methanol was purchased from J. T. Baker (Deventer, The Netherlands) and p.a. formic acid from Merck (Darmstadt, Germany). Folin and Ciocalteu's Phenol Reagent (FC) was provided by Sigma-Aldrich, while sodium carbonate and aluminium(III) chloride were purchased from Centrohem (Stara Pazova, Serbia) and Kemika (Zagreb, Croatia), respectively. William's medium, fetal bovine serum (FBS), penicillinstreptomycin mixture, phosphate-buffered saline (PBS), trypsin from porcine pancreas, dimethyl sulfoxide (DMSO), and 3-(4,5-dimethylthiazol-2-yl)-2,5-diphenyltetrazolium bro- 
mide (MTT) were purchased from Sigma-Aldrich (Steinheim, Germany). Reagents for apoptosis and cell cycle assay were obtained from Invitrogen Life Technologies ${ }^{\text {TM }}$ (FITCAnexinV, Binding puffers 2x, Rnase A Pure Link ${ }^{\mathrm{TM}}$, Waltham, MA, USA) and 7- amino actinomycin D was provided from Pharmingen ${ }^{\mathrm{TM}}$ (Franklin Lakes, NJ, USA). Trizol reagent, Power SYBR green PCR master mix and specific primers for qRT-PCR were obtained from Invitrogen Life Technologies ${ }^{\mathrm{TM}}$ (Carlsbad, CA, USA). Doxorubicin (D, Cas. No. 25316-40-9) was provided by Actavis, S.C. Sindan-Pharma S.R.L. (Buchurești, Romania). All the other chemicals and reagents were purchased from local companies and were of a molecular biology grade.

\subsection{Plant Material, Extracts Preparation, and Chemical Analysis}

Aerial parts of P. aviculare and P. amphibia were collected at Vlasina Lake (N42 $42^{\prime} 40.09^{\prime \prime}$ E22 $\left.2^{\circ} 0^{\prime} 32.942^{\prime \prime}\right)$ in Serbia. Plant materials were identified and the voucher specimens were deposited at the Herbarium of Department of Biology and Ecology, Faculty of Natural Sciences, University of Novi Sad, Serbia (BUNS Herbarium; voucher numbers for P. aviculare and P. amphibia are 2-1669 and 2-1691, respectively).

Extracts were prepared by the maceration of air dried and powdered aboveground plant material $(10 \mathrm{~g})$ with $80 \%$ ethanol $(100 \mathrm{~mL})$ for $72 \mathrm{~h}$ under constant stirring at room temperature. Extracts were removed from plant material by filtration and after vacuum drying, yield of dry raw extracts were: $1.31 \mathrm{~g} / 13.1 \%$ (P. aviculare) and $1.32 \mathrm{~g} / 13.2 \%$ (P. amphibia). Raw extracts were suspended in water and purified by liquid-liquid extraction with petroleum ether, to remove chlorophyll and other ballasts. Defatting of the extracts with petroleum ether can lead to losses of the compounds of interest [24,25], so the petroleum ether layer was washed with methanol and methanol fraction pooled with water layer. After purification, herb extracts yield decreased for $1.1 \%$ (1.20 g; P. aviculare $)$ and for $0.8 \%$ (1.23 g; P. amphibia). Vacuum dried $\left(<45^{\circ} \mathrm{C}\right)$ purified extracts were dissolved in DMSO to a final concentration of $100 \mathrm{mg} / \mathrm{mL}$.

The phytochemical profiles of P. aviculare and P. amphibia were evaluated by measuring the total phenolic content (by means of Folin-Ciocalteu reagent under alkaline conditions) and total flavonoids content (based on aluminum-flavonoids complex formation). Detailed procedure of these two spectrophotometric methods was previously published by Beara et al. [26]. Quantitative LC-MS/MS analysis of selected 45 secondary metabolites was carried out according to the previously reported method [27]. Standard mixture (containing 45 phenolics) was double diluted with mobile phase solvents: A (0.05\% aqueous formic acid): $B$ (methanol), in 1:1 ratio, to obtain fifteen working standards (from $25,000 \mathrm{ng} / \mathrm{mL}$ to $1.53 \mathrm{ng} / \mathrm{mL})$. Extracts were diluted also with solvents A:B (1:1) to a final concentration of $2 \mathrm{mg} / \mathrm{mL}$. Samples and standards were analyzed using Agilent Technologies 1200 Series high-performance liquid chromatograph coupled with Agilent Technologies 6410A Triple Quad tandem mass spectrometer with electrospray ion source (ESI), and controlled by Agilent Technologies MassHunter Workstation software-Data Acquisition (ver. B.03.01). The detailed procedure and method validation were published previously [27] (Supplementary material).

Qualitative LC-DAD-MS analysis of extracts was performed on Agilent Technologies 1200 Series HPLC with DAD, coupled with Agilent Technologies 6410A Triple Quad tandem mass spectrometer with electrospray ion source, and controlled by Agilent Technologies MassHunter Workstation software-Data Acquisition (ver. B.03.01). Working solution of standard mixture- $45(1.56 \mu \mathrm{g} / \mathrm{mL})$ and $5 \mu \mathrm{L}$ of extracts $(20 \mathrm{mg} / \mathrm{mL}$ diluted with A:B (1:1)) were injected into the system, with Zorbax Eclipse XDB-C18 (50 mm, $4.6 \mathrm{~mm}, 1.8$ $\mu \mathrm{m})$ rapid resolution column held at $50{ }^{\circ} \mathrm{C}$. Mobile phase $\mathrm{A}(0.05 \%$ aqueous formic acid) and $\mathrm{B}$ (methanol) was delivered at flow rate of $0.8 \mathrm{~mL} / \mathrm{min}$ in a gradient mode $(0 \mathrm{~min}$ $20 \% \mathrm{~B}, 6.67 \mathrm{~min} 60 \% \mathrm{~B}, 8.33 \mathrm{~min} 100 \% \mathrm{~B}, 12.5 \mathrm{~min} 100 \% \mathrm{~B}$, re-equilibration time $4 \mathrm{~min})$. Eluted components were firstly recorded on diode array detector (DAD), full spectra in 190-700 nm range, chromatograms were acquired at $254 \mathrm{~nm}, 340 \mathrm{~nm}$ and $430 \mathrm{~nm}$; and secondly on triple quadrupole mass spectrometer, using MS2Scan run mode (both, positive 
and negative ionization, $\mathrm{m} / \mathrm{z}$ range of 120-1000 and fragmentor voltage of $80 \mathrm{~V})$. ESI ion source parameters were as follows: nebulization gas $\left(\mathrm{N}_{2}\right)$ pressure 40 psi, drying gas $\left(\mathrm{N}_{2}\right)$ flow $9 \mathrm{~L} / \mathrm{min}$ and temperature $350{ }^{\circ} \mathrm{C}$, capillary voltage $4 \mathrm{kV}$.

\subsection{Human Cell Line}

The human cell line used in this study was hepatocellular carcinoma HepG2 (ATCC HB-8065, Manassas, VA, USA). HepG2 cells were grown in William's medium, with 15\% fetal bovine serum, $1 \%$ penicillin/streptomycin, and $2 \mathrm{mM}$ of L-glutamine. The cell line was maintained in an incubator at $37{ }^{\circ} \mathrm{C}$ with $5.0 \% \mathrm{CO}_{2}$ in a humidified atmosphere. The cells were sub-cultured at $90 \%$ confluence, twice a week, using $0.1 \%$ trypsin. Cell viability was determined by the trypan blue dye exclusion method. Cells in the logarithmic growth phase were used in all experiments.

\subsection{Cytotoxicity and Drug Synergism Analysis}

The cytotoxic effects of plant extracts and D, both as single compounds and in a mixture, were assessed by MTT assay, as described by Jovanović et al. [28]. HepG2 cells were seeded into 96-well plates at a density $2 \times 10^{4}$ cells / well and incubated overnight with $5 \% \mathrm{CO}_{2}$ at $37^{\circ} \mathrm{C}$. Further on, the cells were exposed to a series of two-fold dilutions of extracts and $\mathrm{D}$ in the ranges $4000-125 \mu \mathrm{g} / \mathrm{mL}$ and $22.8-0.712 \mu \mathrm{g} / \mathrm{mL}$, respectively. To prepare mixtures of extracts and $\mathrm{D}$, the highest concentrations of each substance were combined and subsequently diluted two-fold. This process was repeated until reaching $125 \mu \mathrm{g} / \mathrm{mL}$ and $0.712 \mu \mathrm{g} / \mathrm{mL}$ of extracts and D, respectively. After the incubation for $24 \mathrm{~h}$, the medium with test substances was replaced with MTT (final concentration $0.5 \mathrm{mg} / \mathrm{mL}$ ) and incubated for additional $3 \mathrm{~h}$. At the end of incubation with MTT, the medium was removed, and the formazan crystals were dissolved in DMSO. The optical density was measured at $570 \mathrm{~nm}$, using a micro-plate reading spectrophotometer (Multiskan FC, Thermo Scientific, Shanghai, China). Three independent experiments were conducted.

To evaluate the nature of interaction between extracts and D, combination index (CI) analysis was used, providing quantitative definition for the additive effect $(\mathrm{CI}=$ $1)$, synergism $(C I<1)$, and antagonism $(C I>1)$ in drug combinations [29]. The CI was calculated for $\mathrm{IC}_{25}$ and $\mathrm{IC}_{50}$ values of the mixtures, using the formula: $\mathrm{CI}=\mathrm{C}_{\mathrm{A}} / \mathrm{IC}_{\mathrm{A}}+$ $\mathrm{C}_{\mathrm{B}} / \mathrm{IC}_{\mathrm{B}}$, where $\mathrm{C}_{\mathrm{A}}$ is the concentration of the first test substance in the binary mixture; $I_{A}$ is the concentration of the first test substance alone; $C_{B}$ is the concentration of the second test substance in the binary mixture; and $\mathrm{IC}_{\mathrm{B}}$ is the concentration of the second test substance alone.

\subsection{Flow Cytometry Analysis of Apoptosis and Cell Cycle Phase Distribution}

Apoptotic cell death and analysis of the cell cycle phase distribution were analyzed using a fluorescence-activated cell sorting flow cytometer (FACS) (Calibur Becton Dickinson, Heidelberg, Germany) and Cell Quest computer software, according to manufacturer's protocol. HepG2 $\left(1 \times 10^{6}\right.$ cells/well) was cultured with plant extracts with and without D. Concentrations of tested substances were selected in accordance with the results of the MTT assay. $\mathrm{IC}_{50}$ values of extracts and D, individually and combined, were tested. Apoptotic or necrotic cell death was assessed after the $24 \mathrm{~h}$ treatment. As described by Srdic-Rajic et al. [30], cells were harvested, washed with PBS, and stained with Annexin V FITC and 7- amino actinomycin D (7-AAD). In brief, Annexin V FITC binds to the exposed phosphatidylserine of the early apoptotic cells, whereas 7-AAD labels the late apoptotic/necrotic cells, containing damaged membrane. The numbers of viable (annexin $\mathrm{V} \mathrm{FITC}^{-}$7AAD ${ }^{-}$), early apoptotic (annexin $\mathrm{V} \mathrm{FITC}^{+}$7AAD ${ }^{-}$), and late apoptotic/necrotic (annexin $\mathrm{V} \mathrm{FITC}^{+}$7AAD ${ }^{+}$) cells were determined.

The quantitative analysis of the proportion of cells in different cell cycle phases was performed after the treatment and incubation for $24 \mathrm{~h}$. Cells were harvested and fixed with ice-cold $70 \%$ ethanol at $-20^{\circ} \mathrm{C}$ for $30 \mathrm{~min}$. Subsequently, cells were resuspended in PBS 
containing propidium iodide and RNase A and incubated for $30 \mathrm{~min}$ at room temperature. The distribution of the cells was measured by FACS analysis, as previously described.

\subsection{Real-Time Quantitative PCR ( $q R T-P C R)$ Analysis}

In order to detect the expression pattern of Keap1 and Nrf2 genes in HepG2 cells, qRT-PCR analysis was conducted as described in Kaisarevic et al. [31], with minor modifications. For the experiment, the cells were seeded into 12 -well plate $\left(10^{6}\right.$ cells/well $)$ and, after $24 \mathrm{~h}$, exposed in duplicates to the selected concentrations of combined extracts and D. The selected concentrations for this assay were the ones that induced $25 \%$ inhibitions of cell survival $\left(\mathrm{IC}_{25}\right)$, considering that the test procedure requires high cell viability. After the $24 \mathrm{~h}$ treatment, the medium was removed, the cells were washed by PBS, and total RNA was extracted using trizol reagent according to supplier's instructions. The quality and quantity of RNA was determined spectrophotometrically by BioSpecnano (Schimadzu Corporation, Kyoto, Japan). Reverse transcription of each total RNA sample $(2 \mu \mathrm{g})$ to cDNA was conducted using High-Capacity cDNA Reverse Transcription Kit with RNase inhibitor (Applied Biosystems). The reverse transcription reaction was conducted in the Veriti Thermal Cycler (Applied Biosystems), under the following incubation conditions: $10 \mathrm{~min}$ at $25^{\circ} \mathrm{C}, 120 \mathrm{~min}$ at $37^{\circ} \mathrm{C}$, and $5 \mathrm{~min}$ at $85^{\circ} \mathrm{C}$. The expression level of Keap1 and Nrf2 were quantified by qPCR, which was conducted on Mastercycler ${ }^{\circledR}$ ep realplex (Eppendorf, Germany). Each PCR system contained cDNA $(15 \mathrm{ng})$ and $500 \mathrm{nM}$ of specific primers for the target mRNA, and the reaction was catalyzed by Power SYBR Green PCR Master Mix, according to the manufacturer's instruction. Cycling conditions were as follows: $50^{\circ} \mathrm{C}$ for $2 \mathrm{~min}, 95^{\circ} \mathrm{C}$ for $10 \mathrm{~min}, 40$ cycles of $95^{\circ} \mathrm{C}$ for $15 \mathrm{~s}$, and $60^{\circ} \mathrm{C}$ for $1 \mathrm{~min}$. Keap1 and $\mathrm{Nrf} 2$ expression was detected with the amplification by 40 cycles. The following primers were used: $5^{\prime}$-GACAGCCTCTGACAACACAAC$3^{\prime}$ (forward for Keap1), 5'-GAAATCAAAGAACCTGTGGC-3' (reverse for Keap1); 5'CCTCAACTATAGCGATGCTGAATCT-3' (forward for Nrf2), 5' -AGGAGTTGGGCATGAG TGAGTAG-3' (reverse for Nrf2); $5^{\prime}$-AGAGCTACGAGCTGCCTGAC-3' (forward for $\beta$ actin), $5^{\prime}$-AGCACTGTGTTGGCGTACAG-3' (reverse for $\beta$-actin). Data were analyzed by GraphPad Prism software with $\beta$-actin as a reference gene, and its expression was not altered by any of the treatments. The relative expression levels of each target were calculated based on the cycle threshold (Ct) method, as described by Voelker et al. [32].

\subsection{Statistical Analysis}

The values obtained from the following tests, MTT assay, apoptosis, cell cycle and qRT-PCR, were analyzed by analysis of variance (One-way ANOVA, Dunnett's multiple comparisons test) using GraphPad Prism 6.0 (GraphPad Software Inc. San Diego, CA, USA). The level of statistical significance was defined as $p \leq 0.05$. To describe the type of pharmacokinetic interactions between extracts and $\mathrm{D}$, the combination index $(\mathrm{CI})$ was calculated, and data from MTT assay were employed. The values of $\mathrm{CI}$ being lower, equal, or higher than $1(\mathrm{CI}<1, \mathrm{CI}=1, \mathrm{CI}>1)$ indicated the synergistic, additive, and antagonistic effect, respectively.

\section{Results}

\subsection{Identification of Compounds in the Extracts}

The results of spectrophotometric measurement of total phenolics and flavonoids content of the extracts were expressed as equivalents of gallic acid per $\mathrm{g}$ of dry extract (eq $\mathrm{GA} / \mathrm{g} \mathrm{DE}$ ) and equivalents of quercetin per $\mathrm{g}$ of dry extract (eq Querc/g DE), respectively. They were determined to be $282.8 \pm 73 \mathrm{mg}$ eq GA/g DE and $306.9 \pm 43 \mathrm{mg}$ eq GA/1g DE, and $28.9 \pm 0.5 \mathrm{mg}$ eq Querc/1g DE and $38.5 \pm 2.0 \mathrm{mg}$ eq Querc/1g DE, for POA and PEA, respectively. The comparison of data concerning phenolics content of POA and PEA is presented in Table 1. The results of the LC-MS/MS analysis (Figure 1) showed that both extracts are rich in phenolic acids and flavonoids. POA is rich in quinic acid $(8.72 \mathrm{mg} / \mathrm{g}$ $\mathrm{DE})$, kaempherol-3-O-glucoside (1.33 mg/g DE), quercetin-3-O-glucoside (1.38 mg/g DE), 
and quercetin-3-O-galactoside ( $3.02 \mathrm{mg} / \mathrm{g} \mathrm{DE})$. PEA is characterized by a high content of aglycone, such as quercetin $(5.50 \mathrm{mg} / \mathrm{g} \mathrm{DE})$ and a high content of quercetin derivatives: quercetin-3-O-galactoside (11.90 mg/g DE), quercetin-3-O-L-rhamnoside $(9.79 \mathrm{mg} / \mathrm{g} \mathrm{DE})$, and quercetin-3-O-glucoside (1.49 mg/g DE). PEA is also rich in free gallic acid $(3.49 \mathrm{mg} / \mathrm{g}$ $\mathrm{DE})$ and epigallocatechin gallate $(1.28 \mathrm{mg} / \mathrm{g} \mathrm{DE})$.

Table 1. Concentrations of phenolics found in Polygonum aviculare (POA) and Persicaria amphibia (PEA) ethanol extracts (expressed as $\mu \mathrm{g}$ of phenolics per gram of dry extract).

\begin{tabular}{|c|c|c|c|c|c|c|}
\hline \multirow{2}{*}{$\begin{array}{c}\text { Class of Secondary } \\
\text { Metabolites }\end{array}$} & \multirow{2}{*}{ Compound } & \multirow{2}{*}{ No ${ }^{a}$} & \multirow{2}{*}{$\begin{array}{l}\mathbf{R t}^{\mathbf{b}} \\
{[\mathrm{min}]}\end{array}$} & \multirow{2}{*}{$\begin{array}{c}\operatorname{LoQ}^{c} \\
{[\mu g / g d e]}\end{array}$} & \multicolumn{2}{|c|}{ Content $[\mu \mathrm{g} / \mathrm{g} \mathrm{dw}]^{\mathrm{d}}$} \\
\hline & & & & & POA & PEA \\
\hline $\begin{array}{l}\text { Cyclohexanecarboxylic } \\
\text { acids }\end{array}$ & Quinic acid & 1 & 0.52 & 5.0 & $(8.7 \pm 0.9) 10^{3}$ & $(8.8 \pm 0.9) 10^{2}$ \\
\hline \multirow[t]{6}{*}{$\begin{array}{l}\text { Hydroxybenzoic } \\
\text { acids }\end{array}$} & Gallic acid & 2 & 0.58 & 10 & $(9.5 \pm 0.8) 10^{2}$ & $(3.5 \pm 0.3) 10^{3}$ \\
\hline & Protocatechuic acid & 3 & 0.79 & 2.0 & $(2.3 \pm 0.2) 10^{2}$ & $(1.9 \pm 0.1) 10^{1}$ \\
\hline & 2,5-dihydroxybenzoic acid & 5 & 1.03 & 3.5 & $(3.0 \pm 0.2) 10^{1}$ & $<$ LoQ \\
\hline & $p$-Hydroxybenzoic acid & 8 & 1.08 & 4.0 & $(3.1 \pm 0.2) 10^{1}$ & $(4.8 \pm 0.3) 10^{1}$ \\
\hline & Vanillic acid & 12 & 1.24 & 50 & $(2.6 \pm 0.8) 10^{1}$ & $(0.3 \pm 0.1) 10^{2}$ \\
\hline & Syringic acid & 13 & 1.31 & 20 & $(1.5 \pm 0.3) 10^{2}$ & $(1.1 \pm 0.2) 10^{2}$ \\
\hline Phenylpropanoids & Cinnamic acid & 36 & 3.91 & 40 & $<$ LoQ & $<$ LoQ \\
\hline \multirow[t]{6}{*}{$\begin{array}{l}\text { Hydroxycinnamic } \\
\text { acids }\end{array}$} & Caffeic acid & 11 & 1.18 & 3.0 & $(2.2 \pm 0.2) 10^{1}$ & $(6.2 \pm 0.4) 10^{1}$ \\
\hline & $p$-Coumaric acid & 14 & 1.69 & 2.0 & $(5.1 \pm 0.4) 10^{1}$ & $(3.7 \pm 0.3) 10^{1}$ \\
\hline & Ferulic acid & 17 & 1.90 & 5.0 & $(2.8 \pm 0.3) 10^{1}$ & $(5.0 \pm 0.5) 10^{1}$ \\
\hline & Sinapic acid & 18 & 1.92 & 20 & $(1.6 \pm 0.2) 10^{1}$ & $(3.9 \pm 0.4) 10^{1}$ \\
\hline & $o$-coumaric acid & 24 & 2.62 & 3.0 & $1.3 \pm 0.1$ & $<$ LoQ \\
\hline & 3,4-dimethoxycinnamic acid & 31 & 2.99 & 25 & $<$ LoQ & $<$ LoQ \\
\hline Chlorogenic acids & 5-O-caffeoylquinic acid & 6 & 0.80 & 3.5 & $(6.9 \pm 0.3) 10^{2}$ & $11.0 \pm 0.5$ \\
\hline \multirow[t]{2}{*}{ Flavan-3-ols } & Catechin & 4 & 0.74 & 25 & $(7.0 \pm 0.7) 10^{2}$ & $(6.5 \pm 0.6) 10^{2}$ \\
\hline & Epicatechin & 10 & 0.95 & 30 & $(8.8 \pm 0.9) 10^{1}$ & $(2.3 \pm 0.2) 10^{2}$ \\
\hline $\begin{array}{l}\text { Flavan-3-ol- } \\
\text { derivatives }\end{array}$ & Epigallocatechin gallate & 7 & 0.81 & 50 & $(1.5 \pm 0.1) 10^{2}$ & $(1.3 \pm 0.1) 10^{3}$ \\
\hline \multirow[t]{3}{*}{ Coumarins } & Esculetin & 9 & 1.13 & 3.0 & $5.1 \pm 0.3$ & $9.1 \pm 0.5$ \\
\hline & Umbelliferone & 15 & 1.73 & 5.0 & $<$ LoQ & $<$ LoQ \\
\hline & Scopoletin & 16 & 1.77 & 3.5 & $1.0 \pm 0.1$ & $11.2 \pm 0.9$ \\
\hline \multirow[t]{5}{*}{ Flavone glycosides } & Luteolin-7-O-glucoside & 20 & 2.13 & 2.5 & $\begin{array}{c}(11.0 \pm 0.3) \\
10^{-1}\end{array}$ & $3.1 \pm 0.1$ \\
\hline & Vitexin & 19 & 1.90 & 2.0 & $3.2 \pm 0.2$ & $<$ LoQ \\
\hline & Apiin & 25 & 2.60 & 1.5 & $<$ LoQ & $<$ LoQ \\
\hline & Apigenin-7-O-glucoside & 26 & 2.81 & 3.0 & $<\operatorname{LoQ}$ & $\begin{array}{c}(6.0 \pm 0.3) \\
10^{-1}\end{array}$ \\
\hline & Baicalin & 32 & 3.4 & 10 & $<$ LoQ & $<$ LoQ \\
\hline \multirow[t]{3}{*}{ Flavones } & Luteolin & 38 & 4.03 & 2.0 & $6.4 \pm 0.3$ & $12.6 \pm 0.6$ \\
\hline & Apigenin & 39 & 4.71 & 5.0 & $(8.5 \pm 0.6) 10^{1}$ & $(4.0 \pm 0.3) 10^{1}$ \\
\hline & Baicalein & 41 & 5.15 & 15 & $<$ LoQ & $<$ LoQ \\
\hline
\end{tabular}


Table 1. Cont.

\begin{tabular}{|c|c|c|c|c|c|c|}
\hline \multirow{2}{*}{$\begin{array}{l}\text { Class of Secondary } \\
\text { Metabolites }\end{array}$} & \multirow{2}{*}{ Compound } & \multirow{2}{*}{ No $^{a}$} & \multirow{2}{*}{$\begin{array}{l}\mathbf{R t}^{\mathrm{b}} \\
{[\mathrm{min}]}\end{array}$} & \multirow{2}{*}{$\begin{array}{c}\text { LoQ }^{c} \\
{[\mu g / g \text { de }]}\end{array}$} & \multicolumn{2}{|c|}{ Content $[\mu \mathrm{g} / \mathrm{g} \mathrm{dw}]^{\mathrm{d}}$} \\
\hline & & & & & POA & PEA \\
\hline & Chrysoeriol & 43 & 4.82 & 2.0 & $\begin{array}{c}(5.0 \pm 0.1) \\
10^{-1}\end{array}$ & $\begin{array}{c}(8.0 \pm 0.4) \\
10^{-1}\end{array}$ \\
\hline Biflavonoid & Amentoflavone & 45 & 5.78 & 2.5 & $<$ LoQ & $<$ LoQ \\
\hline \multirow[t]{5}{*}{ Flavonol-glycosides } & Quercetin-3-O-galactoside & 21 & 2.16 & 3.0 & $(3.0 \pm 0.2) 10^{3}$ & $\begin{array}{c}(11.9 \pm 0.7) \\
10^{3}\end{array}$ \\
\hline & Quercetin-3-O-rutinoside & 22 & 2.33 & 1.5 & $\begin{array}{c}(26.2 \pm 0.8) \\
10^{1}\end{array}$ & $\begin{array}{c}(20.5 \pm 0.6) \\
10^{1}\end{array}$ \\
\hline & Quercetin-3-O-glucoside & 23 & 2.25 & 2.0 & $\begin{array}{c}(13.8 \pm 0.4) \\
10^{2}\end{array}$ & $\begin{array}{c}(14.9 \pm 0.4) \\
10^{2}\end{array}$ \\
\hline & $\begin{array}{l}\text { Quercetin-3-O-L- } \\
\text { rhamnoside }\end{array}$ & 28 & 2.75 & 1.5 & $(1.6 \pm 0.1) 10^{2}$ & $(9.8 \pm 0.6) 10^{3}$ \\
\hline & Kaempferol-3-O-glucoside & 30 & 2.8 & 2.0 & $\begin{array}{c}(13.3 \pm 0.5) \\
10^{2}\end{array}$ & $(2.8 \pm 0.1) 10^{1}$ \\
\hline \multirow[t]{4}{*}{ Flavonols } & Myricetin & 27 & 2.67 & 50 & $\begin{array}{c}(11.1 \pm 0.8) \\
10^{1}\end{array}$ & $(8.6 \pm 0.6) 10^{2}$ \\
\hline & Quercetin & 35 & 3.74 & 50 & $(0.4 \pm 0.1) 10^{3}$ & $(5.5 \pm 1.6) 10^{3}$ \\
\hline & Kaempferol & 40 & 4.55 & 3.0 & $\begin{array}{c}(12.0 \pm 0.8) \\
10^{1}\end{array}$ & $\begin{array}{c}(13.4 \pm 0.9) \\
10^{1}\end{array}$ \\
\hline & Isorhamnetin & 42 & 4.79 & 10 & $5.1 \pm 0.3$ & $8.6 \pm 0.5$ \\
\hline Flavanones & Naringenin & 37 & 3.87 & 3.5 & $6.5 \pm 0.4$ & $(1.6 \pm 0.1) 10^{1}$ \\
\hline \multirow[t]{2}{*}{ Isoflavones } & Daidzein & 33 & 3.43 & 5.0 & $<$ LoQ & $<$ LoQ \\
\hline & Genistein & 44 & 4.12 & 3.0 & $<$ LoQ & $<$ LoQ \\
\hline \multirow[t]{2}{*}{ Lignans } & Secoisolariciresinol & 29 & 2.90 & 25 & $<\operatorname{LoQ}$ & $<$ LoQ \\
\hline & Matairesinol & 34 & 3.66 & 50 & $<\operatorname{LoQ}$ & $<$ LoQ \\
\hline TOTAL & & & & & $18,782(1.88 \%)$ & $37,113(3.71 \%)$ \\
\hline
\end{tabular}

${ }^{a}$ Numbers are used as labels on given chromatograms bellow. ${ }^{b}$ From the method validation published in Orčić et al. [27]. ${ }^{\mathrm{c}}$ Calculated from the instrument quantification limit (Orčić et al. [27]) and sample dilution. ${ }^{\mathrm{d}}$ Results are given as the concentration ( $\mu \mathrm{g} / \mathrm{g}$ of dry extract) \pm relative standard deviation of repeatability (as determined by method validation [27]). LoQ-limit of quantitation; the standard curves were provided in Supporting materials (Figure S1). 


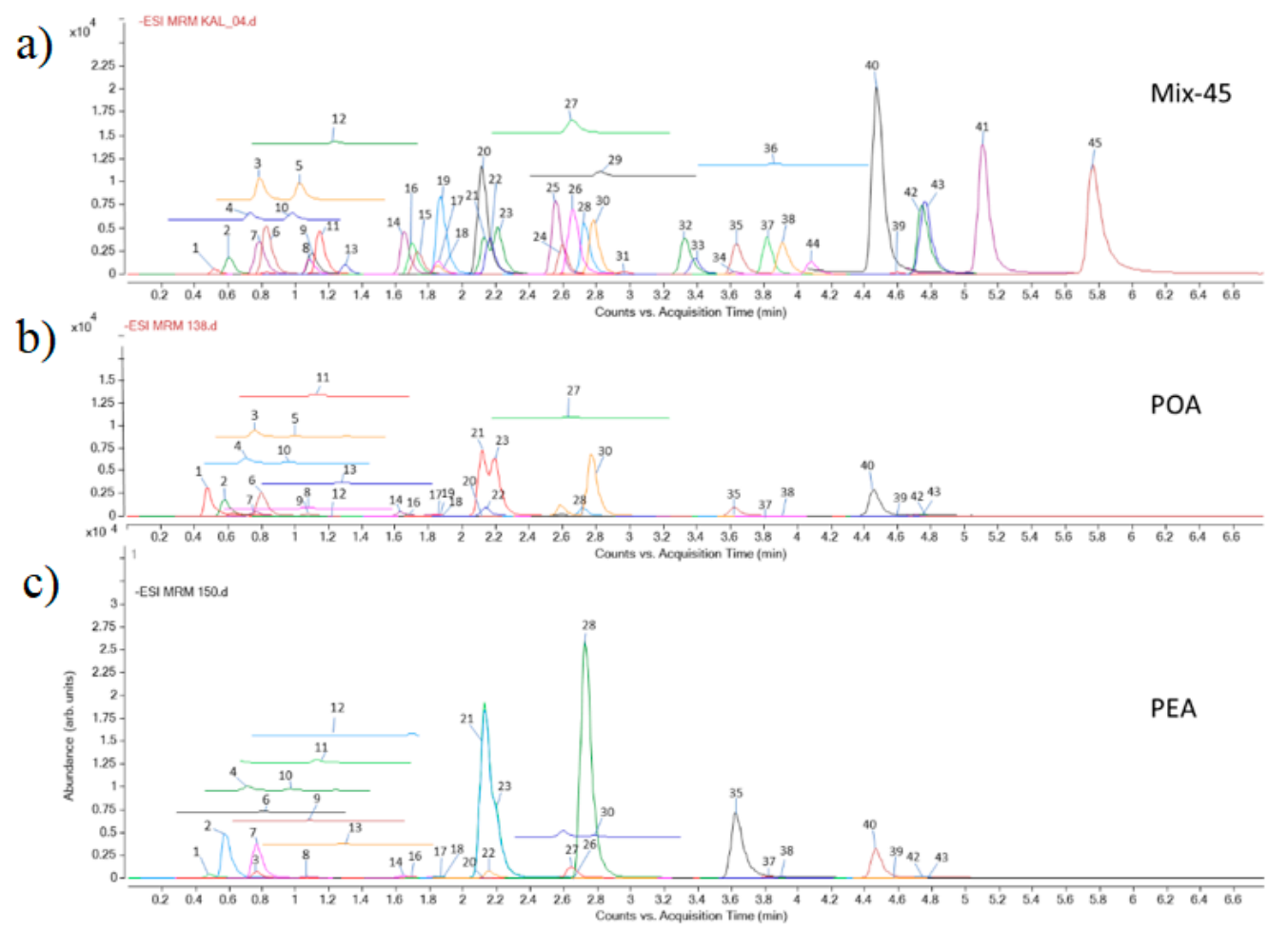

Figure 1. MRM chromatograms of standard compounds $(3.125 \mu \mathrm{g} / \mathrm{mL}$ each standard), (a); of P. aviculare herb ethanol extract, POA, (b); and of P. amphibia herb ethanol extract, PEA, (c); 1: Quinic acid, 2: Gallic acid, 3: Protocatechuic acid, 4: Catechin, 5: 2,5-dihydroxybenzoic acid, 6: 5-O-caffeoylquinic acid, 7: Epigallocatechin gallate, 8: p-Hydroxybenzoic acid, 9: Esculetin, 10: Epicatechin, 11: Caffeic acid, 12: Vanillic acid, 13: Syringic acid, 14: p-Coumaric acid, 15: Umbelliferon, 16: Scopoletin, 17: Ferulic acid, 18: Sinapic acid, 19: Vitexin, 20: Luteolin-7-O-glucoside, 21: Quercetin-3-O-galactoside, 22: Rutin, 23: Quercetin-3-O-glucoside, 24: o-Coumaric acid, 25: Apiin, 26: Apigenin-7-O-glucoside, 27: Myricetin, 28: Quercetin-3-O-L-rhamnoside, 29: Secoisolariciresinol, 30: Kaempferol-3-O-glucoside, 31: 3,4-dimethoxycinnamic acid, 32: Baicalin, 33: Daidzein, 34: Matairesinol, 35: Quercetin, 36: Cinnamic acid, 37: Naringenin, 38: Luteolin, 39: Apigenin, 40: Kaempferol, 41: Baicalein, 42: Isorhamnetin, 43: Chrysoeriol, 44: Genistein, 45: Amentoflavone.

\subsection{Cytotoxicity and Drug Synergism Analysis of Herbal Extracts and Doxorubicin}

The evaluation of the cytotoxic effect of herbal extracts, alone and combined with $\mathrm{D}$, was conducted on HepG2 cells. The $\mathrm{IC}_{25}$ and $\mathrm{IC}_{50}$ values of extracts and $\mathrm{D}$, determined from the dose-response curves (Figure 2A-C), are presented in Table 2. Applied individually, PEA was more effective against HepG2 cells than POA. Applied in a mixture, in lower tested concentrations, POAD induced higher sensitivity of HepG2 cells than PEAD. To quantify the mode of interaction between tested substances, the combination index (CI) was calculated for $\mathrm{IC}_{25}$ and $\mathrm{IC}_{50}$ concentrations. Remarkable synergism for both mixtures, POAD ( $\mathrm{CI}=0.62$ and 0.13$)$ and PEAD $(\mathrm{CI}=0.89$ and 0.39$)$, was detected. Thus, the concentration required to inhibit cell viability for $25 \%$ and $50 \%$ for both agents in the mixtures has been remarkably reduced. 
A)

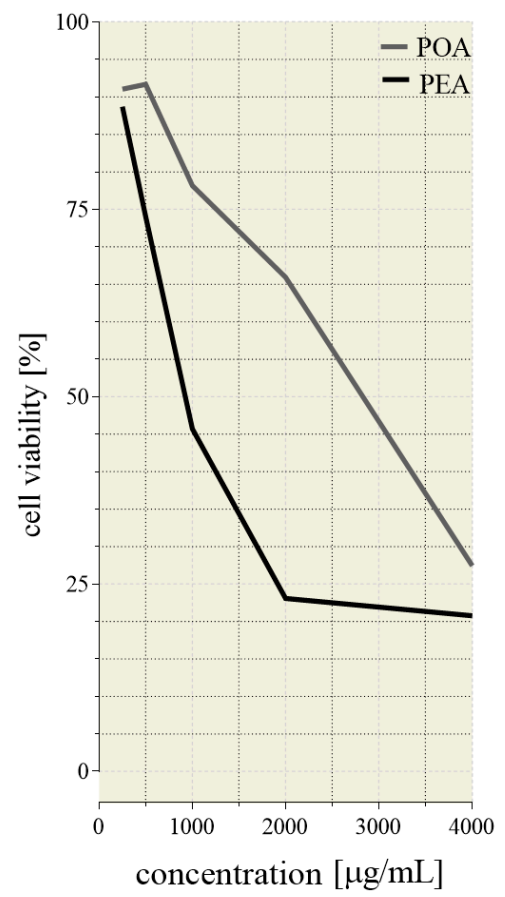

B)

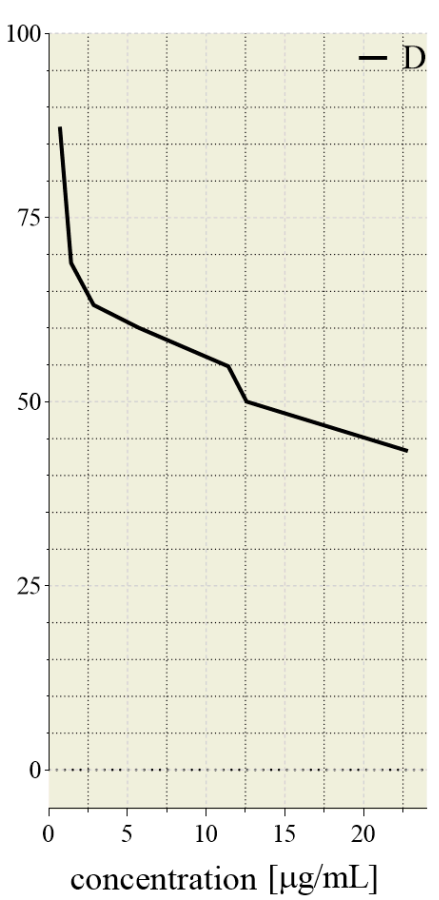

C) concentration of $\mathrm{D}[\mu \mathrm{g} / \mathrm{mL}]$

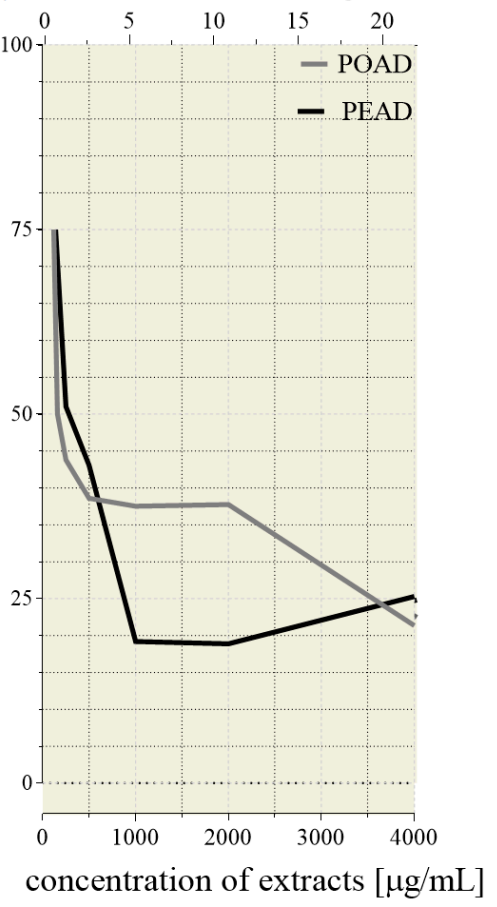

Figure 2. Inhibition rates of HepG2 cells treated with individual extracts (A); doxorubicin (B); and their combination (C) after $24 \mathrm{~h}$.

Table 2. The cytotoxicity of herbal extracts and doxorubicin (D), either alone or in a two-drug combination on HepG2 cells.

\begin{tabular}{|c|c|c|c|}
\hline \multicolumn{4}{|c|}{ Individual Treatments } \\
\hline & $\mathrm{IC}_{25}$ * & & \\
\hline D & 1.3 & & \\
\hline POA & 1250 & & \\
\hline PEA & 500 & & \\
\hline \multicolumn{4}{|c|}{$\mathrm{IC}_{25}$ * values of the co-treatments } \\
\hline \multicolumn{2}{|c|}{ POAD } & \multicolumn{2}{|c|}{ PEAD } \\
\hline POA & $\mathrm{D}$ & PEA & $\mathrm{D}$ \\
\hline 120 & 0.68 & 140 & 0.79 \\
\hline \multicolumn{4}{|c|}{$\mathrm{IC}_{50}{ }^{*}$ values of the co-treatments } \\
\hline \multicolumn{2}{|c|}{ POAD } & \multicolumn{2}{|c|}{ PEAD } \\
\hline POA & $\mathrm{D}$ & PEA & $\mathrm{D}$ \\
\hline \multirow[t]{3}{*}{160} & 0.91 & 250 & 1.43 \\
\hline & \multicolumn{2}{|c|}{$\mathrm{CI}$} & \\
\hline & POAD & & \\
\hline $\mathrm{IC}_{25}$ & 0.62 & & \\
\hline $\mathrm{IC}_{50}$ & 0.13 & & \\
\hline
\end{tabular}

* The concentrations are expressed in $\mu \mathrm{g} / \mathrm{mL}$. Polygonum aviculare ethanol extract (POA); Persicaria amphibia ethanol extract (PEA); Doxorubicin (D); Co-treatment of POA and D (POAD); Co-treatment of PEA and D (PEAD); Combination index (CI). The concentrations in bold, individually and combined, were used in flow cytometry analysis. 


\subsection{Effect of Herbal Extracts and Doxorubicin on Apoptosis and Cell Cycle}

To determine whether the cytotoxicity of individual agents and their combinations is related to apoptosis and mediated by cell cycle arrest, the flow cytometry was applied. A significant increase in early apoptosis was determined after treatment with POA (21\%). (Figure $3 \mathrm{~A}, \mathrm{~B}$ ). In addition, both concentrations of $\mathrm{D}$, used for the preparation of combinations with POA and PEA, also increased early apoptosis of cancer cells (36\% and $48.65 \%$ ). An increase in both early and late apoptosis was observed when the PEA (29\% and $38 \%$, respectively) and POAD ( $26 \%$ and $17 \%$ respectively) were applied. However, in the case of PEAD co-treatment, only an increase in late apoptosis was detected (46.51\%).

A)

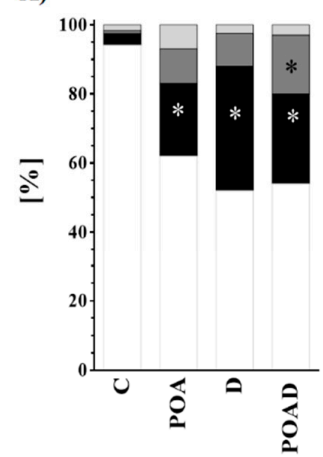

B)

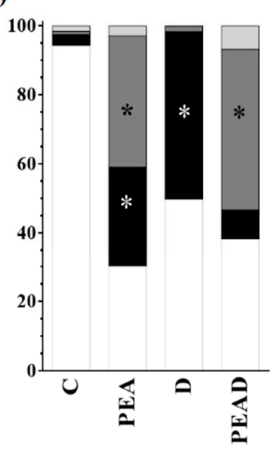

C)

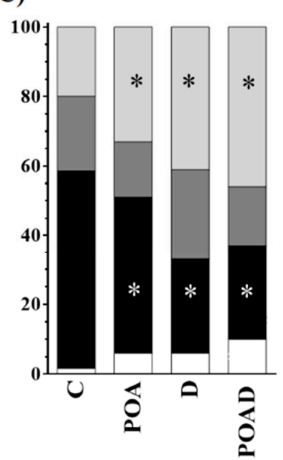

D)

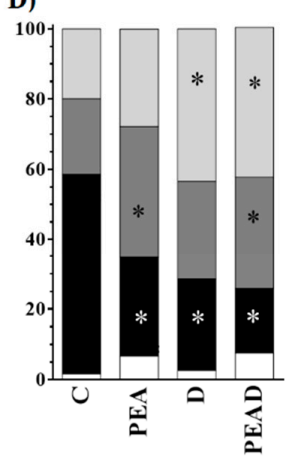

Live cells $\square$ Early apoptosis $\square$ Late apoptosis $\square$ Debris $\square$ subG1 $\square$ G0/G1 $\square \mathrm{S} \square$ G2/M

Figure 3. Analysis of apoptosis (A,B) and cell cycle arrest (C,D) in HepG2 cells after treatment with extracts, doxorubicin (D), and their combinations. An increase in the number of early and late apoptotic cells is always at the expense of living cells; the results are expressed as percentages compared to the untreated control ${ }^{*} p \leq 0.05$.

The analysis of the cell cycle phase distribution of HepG2 treated cells showed a significant cell cycle arrest in G2/M phase when individual treatment, POA (33\%), and both concentration of $\mathrm{D}(41 \%$ and $43.45 \%)$, as well as co-treatments POAD $(46 \%)$ and PEAD (42.69\%) were applied (Figure 3C,D). Additionally, a significant increase in HepG2 cells in $S$ phase was observed after individual treatment with PEA (37.4\%) and co-treatment with $\operatorname{PEAD}(31.84 \%)$.

\subsection{Effect of Herbal Extracts and Doxorubicin on Keap1 and Nrf2 Genes Expression}

In malignant cells, alterations of the expression of Keap1 and Nrf2 genes are not rare. Here, the expression of Nrf2 and Keap1 was examined in HepG2 cells. Both co-treatments significantly increased Keap1 and simultaneously decreased Nrf2 gene expression (Figure 4).

A)

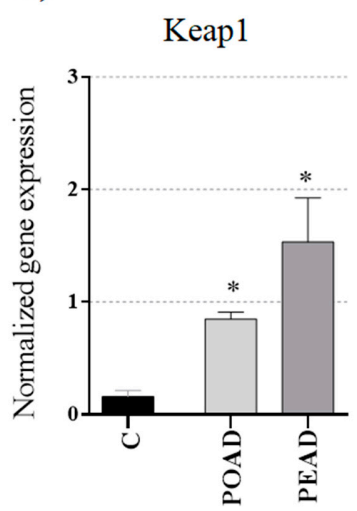

B)

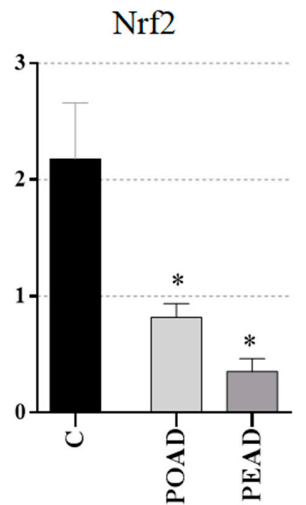

Figure 4. The effect of extracts and doxorubicin (D) combined $\left(\mathrm{IC}_{25}\right)$ on the expression of $(\mathrm{A})$ Keap1 and (B) Nrf2 genes in HepG2 cells evaluated by the qRT-PCR, ${ }^{*} p \leq 0.05$. 


\section{Discussion}

Polygonaceae species are rich sources of valuable secondary metabolites, mainly flavonoids. Data concerning chemical composition of $P$. aviculare is abundant, while P. amphibia has been less studied. Several studies gave important contributions in elucidating chemical composition of P. aviculare extracts [1,33-42], but Granica et al. [43-45], and Cai et al. [46] stands out. Granica et al. [43,44] focused on developing new standardization HPLC methods for P. aviculare. Taking into account the results of Granica [43], we have focused on a targeted search for given flavonol (myricetin $(M)$, quercetin $(Q)$, kaempferol $(\mathrm{K})$, isorhamnetin (IR), kaempferide (KD)) glucuronides (U) and their acetylated derivatives (acU), as some of these tend to be the major compounds occurring in P. aviculare (Q-3-Oglucuronide or kaempherol-3-O-glucuronide). For HPLC separation conditions used in our work there is a pattern of elucidation order, as follows: MU, QU, MacU, KU, IRU, QacU1, QacU2, KacU1, IRacU1, KacU2, IRacU2, KDU, KDacU (Figures 5 and 6) This way of analysis revealed significant differences between $P$. aviculare and $P$. amphibia plant extracts. Although both plant extracts contain myricetin-glucuronide and quercetin-glucuronide in significant amounts (not quantified), in PEA extracts the following compounds were not found: MacU, IRU, QacU1, QacU2, KacU1, IRacU1, KacU2, IRacU2, KDU, KDacU. Considering the scarce data on chemical composition of P. amphibia $[34,35,42,47]$ this work, with quantitative and tentative qualitative HPLC analysis, creates a notable contribution.

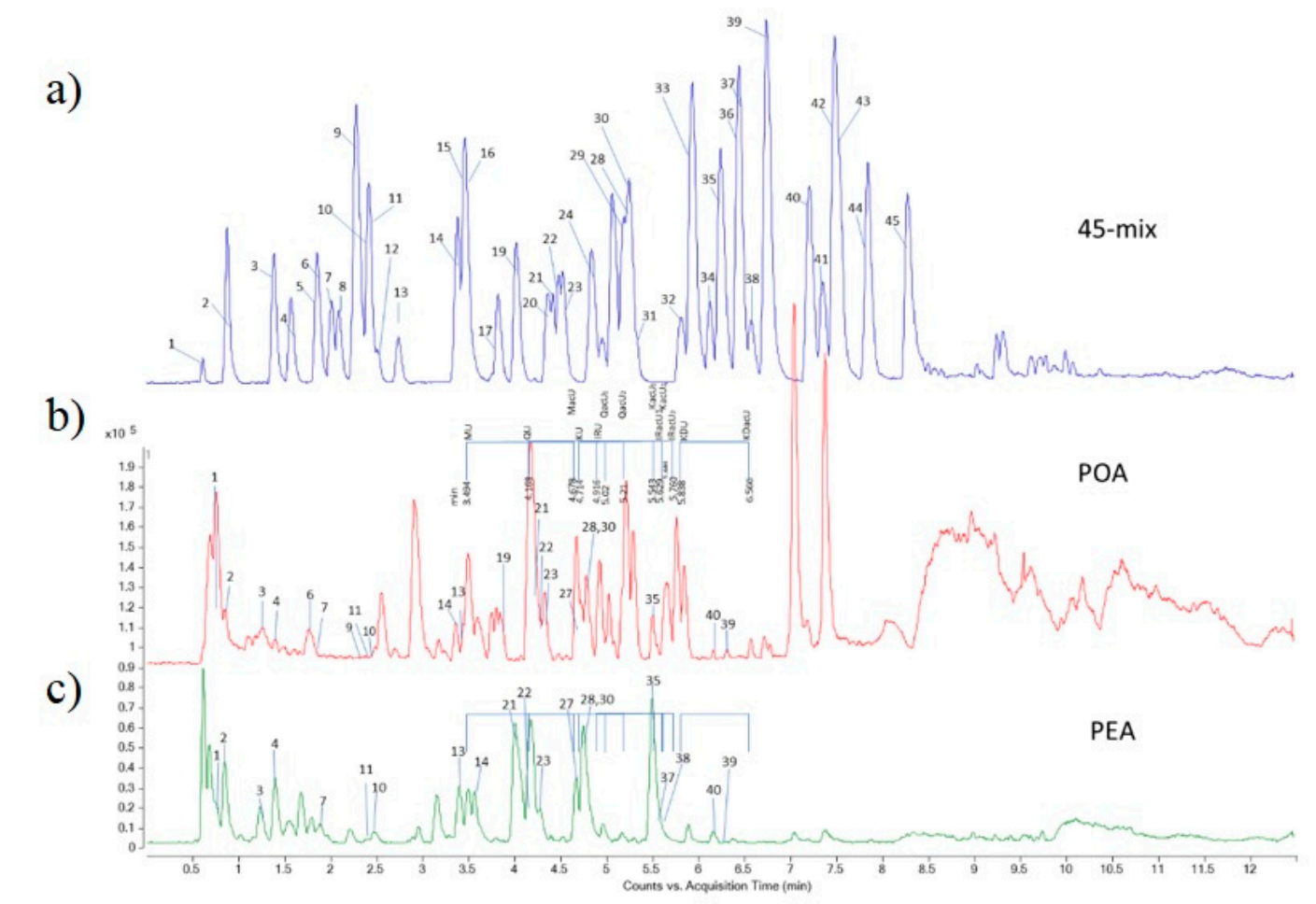

Figure 5. ESI BPC chromatograms, negative ionization mode (MS2Scan) of standard mix-45 (1.56 $\mu \mathrm{g} / \mathrm{mL}$, each compound), (a); of Polygonum aviculare ethanol herb extract, POA, (b); and Persicaria amphibia ethanol herb extract, PEA, (c); with labeled phenolics that were confirmed by quantitative LC-MS/MS analysis, and tentatively determined -glucuronides (U), and acetylglucuronides (acU) derivatives of Myricetin (M), Quercetin (Q), Kaempferol (K), Isorhamenetin (IR) and Kaempferide (KD), e.g., MU-myricetin-glucuronide, MacU-myricetinacetylglucuronide (Tables S1 and S2). 
a)

b)

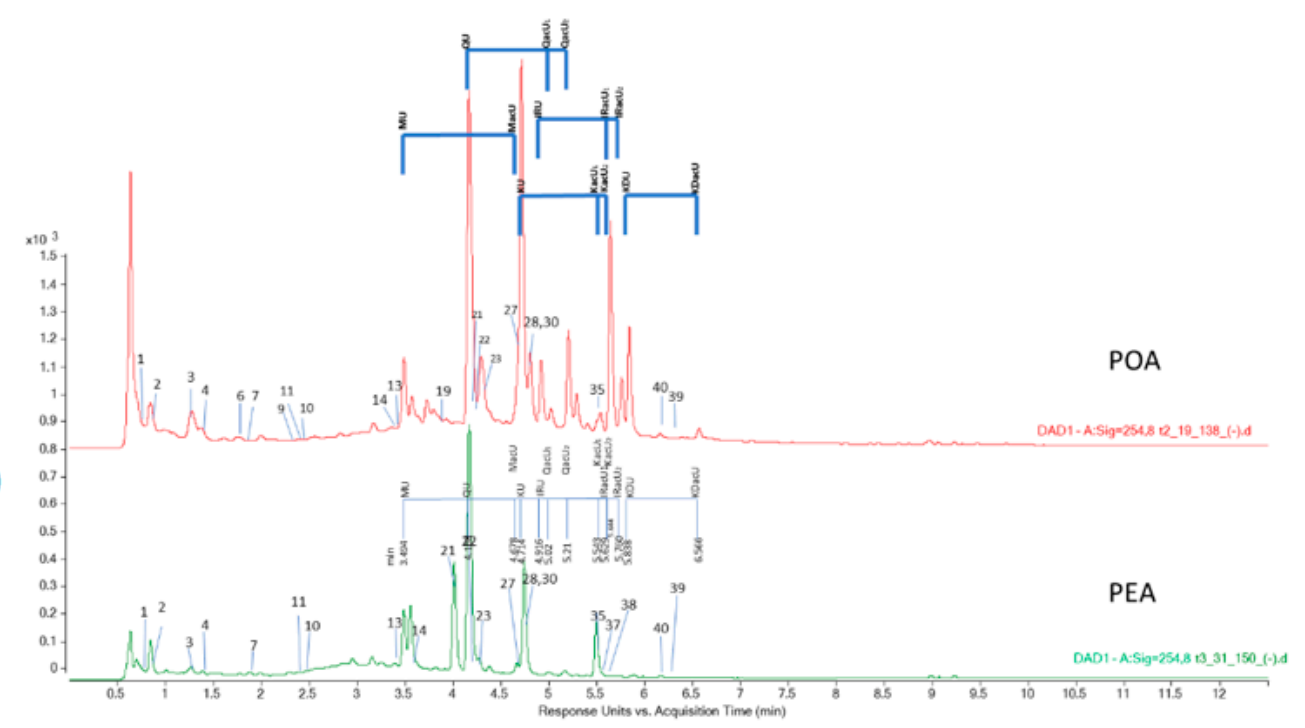

Figure 6. HPLC-DAD chromatograms $(255 \mathrm{~nm})$ of Polygonum aviculare ethanol herb extract, POA, (a); and Persicaria amphibia ethanol herb extract, PEA, (b); with labeled phenolics that were confirmed by quantitative LC-MS-MS analysis. Tentatively determined -glucuronides (U), and acetylglucuronides (acU) derivatives of Myricetin (M), Quercetin (Q), Kaempferol (K), Isorhamenetin (IR) and Kaempferide (KD) are also labeled, e.g., MU-myricetin-glucuronide, MacUmyricetinacetylglucuronide (Figure S2).

On the other hand, to overcome the problem of overall toxicity and resistance of cancer cells to chemotherapeutics, a combined approach that employs both commercial cytostatic and herbal extracts was subjected to the analysis. The benefit of this approach involves the induction of more diverse mechanisms of action that hinder the development of resistance and allow for the reduction of cytostatic doses. In this study, we examined in vitro cytotoxic properties of POA and PEA, alone and combined with commercial cytostatic D. Our investigation provided corroborative evidence that POA and PEA extract could potentiate D cytotoxicity in hepatocarcinoma (HepG2) cells. This result is in accordance with our previous findings [28], which demonstrated a synergistic interaction between Polygonum maritimum extract and D in HepG2 cells. Likewise, Ghazali et al. [48] demonstrated that herb extracts obtained from Polygonum minus have an antiproliferative effect on HepG2 cells. It has also been reported that the Polygonum cuspidatum extract has an antiproliferative effect on hepatocarcinoma cells Bel-7402 and Hepa 1-6 [49], whereas extracts obtained from Polygonum glabrum and Polygonum orientale exhibited the protective activity on normal hepatocytes in vivo [50,51].

It is well known that inhibition of cancer cell proliferation may be a result of a proapoptotic effect and a cell cycle disruption. Consequently, the effect of extracts and their combinations with $\mathrm{D}$ on apoptosis and cell cycle arrest were monitored. Herein, it was confirmed that apoptosis induction plays an important role in D-induced cell death of HepG2 cells. Also, all treatments, but particularly with POA, applied alone and in a combination, were capable of inducing early or late apoptosis. Similar to this finding, Habibi et al. [7] have reported that methanol extract of P. aviculare induced apoptosis in breast cancer MCF-7 cells. As for the impact of Polygonum spp. extracts on the molecular mechanism of apoptosis, up-regulation of the apoptotic gene $p 53$ and down-regulation of the anti-apoptotic $B c l-2$ gene were demonstrated [7]. The pro-apoptotic effect controlled by p53 is accompanied by cell cycle arrest in G2/M phase [52]. Further on, the arrest of the cell cycle in G2/M phase is a well-established feature of D [53]. Importantly, the G2/M checkpoint serves to prevent damaged cells from entering mitosis and proliferate. Not only $\mathrm{D}$, but also the extracts, particularly POA alone and combined with $\mathrm{D}$, increased the number of HepG2 cells in the G2/M phase. Likewise, recent studies have shown that various Polygonum spp. extracts and their active compounds induced the pro-apoptotic 
effect and arrested HepG2 cells in G2/M phase [54,55]. Moreover, this study demonstrated that PEA alone and combined with D induced cell cycle arrest in the S phase. The obtained results are in line with Ghazali et al. [48], implying that Polygonum minus extracts induced $S$ phase cell cycle arrest in HepG2 cells. Therefore, the observed synergism between D and tested extracts in cancer cells might be attributed to the interference with pathways involved in the regulation of apoptosis and cell cycles.

Data reported in the literature indicates that pro-apoptotic effects and cell cycle arrest induced by plant extracts could be attributed to their chemical composition. Searching for possible active compounds among the main constituents of the tested extracts pointed to free gallic acid, as well as quercetin and its derivatives, since they have been well documented to possess cytotoxicity linked to pro-apoptotic effects and the ability to induce cell cycle arrest [56-58]. Thus, quercetin caused the cell cycle arrest in G2/M phase, which was followed by a decrease in cell numbers in the G0/G1 phase [58]. Furthermore, gallic acid induced cell cycle arrest in malignant cells, contributing to inhibition of cancerous cell proliferation [59]. Moreover, quercetin induced apoptosis in various cancer cells [60,61].

Beside the growth-inhibiting and apoptosis-inducing effects, phytochemicals are capable of modulating Nrf2 expression. Furthermore, due to the overexpression of Nrf2, malignant cells are frequently highly resistant to different chemotherapeutics $[19,21]$. Therefore, Nrf2 is an important pharmacological target of effective chemotherapy. This study demonstrated that both co-treatments decreased Nrf2 expression in HepG2 cells. As expected, this response was followed by increased Keap1 gene expression. Similar results were obtained for resveratrol, an active compound of Polygonum cuspidatum, which was shown to modulate Nrf2 expression in a concentration- and time-dependent way [62]. Comprehensively observed, Nrf2 has a functional link with numerous genes reported to play specific roles in the development of drug resistance. For instance, Nrf2 influences the regulation of phase II-detoxifying enzymes, antioxidant defense enzymes, and multidrug resistance-associated proteins 1-6 (MRP 1-6) [23,63]. Altogether, regulation of Nrf2 is responsible, at least partially, for chemotherapy resistance, indicating the importance of determining Nrf2 inhibitors, such as POAD and PEAD.

In conclusion, since synergistic cytotoxicity in hepatocarcinoma cells was observed, the combined approach that employs Polygonum aviculare and Persicaria amphibia ethanol extracts and cytostatic D, could serve as a good starting point in the search for hepatocarcinoma chemotherapy improvement.

Supplementary Materials: The following are available online at https:/ / www.mdpi.com/article/ 10.3390/foods10040811/s1, Figure S1: Calibration curves of standards (34 out of 45) which presence was detected in analysed extracts, Figure S2: Extract Ion Chromatograms: -EIC: 493-,477-,461-,491-,535-, 519-,475-,503-,533-,517-,317-,301-,285-,315-,299- indicating the significant differences in flavonol-glucronides composition in P. aviculare and P. amphibia species, Table S1: Identification of the main compounds from Polygonum aviculare ethanol extracts (POA) by HPLC-DAD-MS, Table S2 Identification of the main compounds from Persicaria amphibia ethanol extracts (PEA) by HPLC-DAD-MS.

Author Contributions: Conceptualization, D.M.-Ć., B.N., and M.J.; methodology, T.S.-R., E.S., D.T., and M.J.; validation, B.N.; formal analysis, T.S.-R., E.S., D.T., and M.J.; investigation, M.J., D.M.-Ć., and B.N.; resources, D.M.-Ć.; data curation, E.S., T.S.-R., and D.T.; writing-original draft preparation, M.J.; writing—review and editing, B.N., D.M.-Ć., and E.S.; visualization, M.J.; supervision, D.M.-Ć., B.N., and T.S.-R.; project administration, D.M.-Ć.; funding acquisition, D.M.-Ć., and M.J.; All authors have read and agreed to the published version of the manuscript.

Funding: This work was supported by Ministry of Education, Science, and Technological Development of Republic of Serbia (451-03-68/2020-14/200178 and 200051).

Data Availability Statement: The data presented in this study are available on request from the corresponding author.

Acknowledgments: The authors are grateful to Bojana Žegura, National Institute of Biology, Slovenia, for providing HepG2 cells for this work and to Goran Anačkov, University of Novi Sad-Faculty of Sciences, Serbia, for identifying plant material. 
Conflicts of Interest: The authors declare no conflict of interest.

\section{References}

1. Nugroho, A.; Kim, E.J.; Choi, J.S.; Park, H.J. Simultaneous quantification and peroxynitrite-scavenging activities of flavonoids in Polygonum aviculare L. herb. J. Pharm. Biomed. Anal. 2014, 89, 93-98. [CrossRef] [PubMed]

2. Özbay, H.; Alim, A. Antimicrobial activity of some water plants from the northeastern Anatolian region of Turkey. Molecules 2009, 14, 321-328. [CrossRef]

3. Chon, S.U.; Heo, B.G.; Park, Y.S.; Cho, J.Y.; Gorinstein, S. Characteristics of the leaf parts of some traditional Korean salad plants used for food. J. Sci. Food Agric. 2008, 88, 1963-1968. [CrossRef]

4. Costea, M.; Tardif, F.J. The biology of Canadian weeds. 131. Polygonum aviculare L. Can. J. Plant Sci. 2005, 85, 481-506. [CrossRef]

5. Thu, N.N.; Sakurai, C.; Uto, H.; Van Chuyen, N.; Do, T.K.; Yamamoto, S.; Ohmori, R.; Kondo, K. The polyphenol content and antioxidant activities of the main edible vegetables in northern Vietnam. J. Nutr. Sci. Vitaminol. 2004, 50, 203-210. [CrossRef]

6. Shikov, A.N.; Pozharitskaya, O.N.; Makarov, V.G.; Wagner, H.; Verpoorte, R.; Heinrich, M. Medicinal plants of the Russian Pharmacopoeia; their history and applications. J. Ethnopharmacol. 2014, 154, 481-536. [CrossRef]

7. Habibi, R.M.; Mohammadi, R.A.; Delazar, A.; Halabian, R.; Soleimani, R.J.; Mehdipour, A.; Bagheri, M.; Jahanian-Najafabadi, A. Effects of Polygonum aviculare herbal extract on proliferation and apoptotic gene expression of MCF-7. Daru J. Pharm. Sci. 2011, 19,326 .

8. Zlatković, B.K.; Bogosavljević, S.S.; Radivojević, A.R.; Pavlović, M.A. Traditional use of the native medicinal plant resource of Mt. Rtanj (Eastern Serbia): Ethnobotanical evaluation and comparison. J. Ethnopharmacol. 2014, 151, 704-713. [CrossRef] [PubMed]

9. Bolotova, Y.V. Aquatic plants of the Far East of Russia: A review on their use in medicine, pharmacological activity. BJMS 2015, 14, 9-13. [CrossRef]

10. Ravipati, A.S.; Zhang, L.; Koyyalamudi, S.R.; Jeong, S.C.; Reddy, N.; Bartlett, J.; Smith, P.T.; Shanmugam, K.; Münch, G.; Wu, M.J.; et al. Antioxidant and anti-inflammatory activities of selected Chinese medicinal plants and their relation with antioxidant content. BMC Complement. Altern. Med. 2012, 12, 173. [CrossRef] [PubMed]

11. Hsu, C.Y. Antioxidant activity of extract from Polygonum aviculare L. Biol. Res. 2006, 39, 281-288. [CrossRef] [PubMed]

12. Prota, N.; Mumm, R.; Bouwmeester, H.J.; Jongsma, M.A. Comparison of the chemical composition of three species of smart-weed (genus Persicaria) with a focus on drimane sesquiterpenoids. Phytochemistry 2014, 108, 129-136. [CrossRef]

13. Orbán-Gyapai, O.; Lajter, I.; Hohmann, J.; Jakab, G.; Vasas, A. Xanthine oxidase inhibitory activity of extracts prepared from Polygonaceae species. Phytother. Res. 2015, 29, 459-465. [CrossRef] [PubMed]

14. Sung, Y.Y.; Yoon, T.; Yang, W.K.; Kim, S.J.; Kim, D.S.; Kim, H.K. The antiobesity effect of Polygonum aviculare L. ethanol extract in high-fat diet-induced obese mice. Evid. Based Complement. Alternat. Med. 2013, 2013, 626397. [CrossRef] [PubMed]

15. Dong, X.; Fu, J.; Yin, X.; Li, X.; Wang, B.; Cao, S.; Zhang, J.; Zhang, H.; Zhao, Y.; Ni, J. Pharmacological and other Bioactivities of the Genus Polygonum-A Review. Trop. J. Pharm. Res. 2014, 13, 1749-1759.

16. Zhu, A.X. Systemic therapy of advanced hepatocellular carcinoma: How hopeful should we be? Oncologist 2006, 11, 790-800. [CrossRef]

17. Tu, D.G.; Chyau, C.C.; Chen, S.Y.; Chu, H.L.; Wang, S.C.; Duh, P.D. Antiproliferative Effect and Mediation of Apoptosis in Human Hepatoma HepG2 Cells Induced by Djulis Husk and Its Bioactive Compounds. Foods 2020, 9, 1514. [CrossRef]

18. Eid, S.Y.; El-Readi, M.Z.; Wink, M. Synergism of three-drug combinations of sanguinarine and other plant secondary metab-olites with digitonin and doxorubicin in multi-drug resistant cancer cells. Phytomedicine 2012, 19, 1288-1297. [CrossRef]

19. Gao, A.M.; Ke, Z.P.; Shi, F.; Sun, G.C.; Chen, H. Chrysin enhances sensitivity of BEL-7402/ADM cells to doxorubicin by suppressing PI3K/Akt/Nrf2 and ERK/Nrf2 pathway. Chem. Biol. Interact. 2013, 206, 100-108. [CrossRef]

20. Shafa, M.H.; Jalal, R.; Kosari, N.; Rahmani, F. Efficacy of metformin in mediating cellular uptake and inducing apoptosis activity of doxorubicin. Regul. Toxicol. Pharmacol. 2018, 99, 200-212. [CrossRef]

21. Lee, Y.J.; Lee, D.M.; Lee, S.H. Nrf2 expression and apoptosis in quercetin-treated malignant mesothelioma cells. Mol. Cells 2015, 38, 416. [CrossRef]

22. Raghunath, A.; Sundarraj, K.; Arfuso, F.; Sethi, G.; Perumal, E. Dysregulation of Nrf2 in hepatocellular carcinoma: Role in cancer progression and chemoresistance. Cancers 2018, 10, 481. [CrossRef]

23. Dong, L.; Han, X.; Tao, X.; Xu, L.; Xu, Y.; Fang, L.; Yin, L.; Qi, Y.; Li, H.; Peng, J. Protection by the total flavonoids from Rosa laevigata Michx fruit against lipopolysaccharide-induced liver injury in mice via modulation of FXR signaling. Foods $2018,7,88$. [CrossRef]

24. Šibul, F.S.; Orčić, D.Z.; Svirčev, E.; Mimica-Dukić, N.M. Optimization of extraction conditions for secondary biomolecules from various plant species. Hem. Ind. 2016, 70, 473-483. [CrossRef]

25. Zhang, C.; Liu, D.; Wu, L.; Zhang, J.; Li, X.; Wu, W. Chemical characterization and antioxidant properties of ethanolic extract and its fractions from sweet potato (Ipomoea batatas L.) leaves. Foods 2020, 9, 15. [CrossRef] [PubMed]

26. Beara, I.N.; Lesjak, M.M.; Jovin, E.Đ.; Balog, K.J.; Anackov, G.T.; Orcic, D.Z.; Mimica-Dukic, N.M. Plantain (Plantago L.) species as novel sources of flavonoid antioxidants. J. Agric. Food Chem. 2009, 57, 9268-9273. [CrossRef] [PubMed]

27. Orčić, D.; Francišković, M.; Bekvalac, K.; Svirčev, E.; Beara, I.; Lesjak, M.; Mimica-Dukić, N. Quantitative Determination of Plant Phenolics in Urtica dioica Extracts by High-Performance Liquid Chromatography Coupled with Tandem Mass Spec-trometric Detection. Food Chem. 2014, 143, 48-53. [CrossRef] 
28. Jovanović, M.; Srdić-Rajić, T.; Svirčev, E.; Jasnić, N.; Nikolić, B.; Bojić, S.; Stević, T.; Knežević-Vukčević, J.; Mitić-Ćulafić, D. Evaluation of anticancer and antimicrobial activities of the Polygonum maritimum ethanol extract. Arch. Biol. Sci. 2018, 70, 665-673. [CrossRef]

29. Vasilijević, B.; Knežević-Vukčević, J.; Mitić-Ćulafić, D.; Orčić, D.; Francišković, M.; Srdic-Rajic, T.; Jovanović, M.; Nikolić, B. Chemical characterization, antioxidant, genotoxic and in vitro cytotoxic activity assessment of Juniperus communis var. sax-atilis. Food Chem. Toxicol. 2018, 112, 118-125. [CrossRef] [PubMed]

30. Srdic-Rajic, T.; Nikolic, K.; Cavic, M.; Djokic, I.; Gemovic, B.; Perovic, V.; Veljkovic, N. Rilmenidine suppresses proliferation and promotes apoptosis via the mitochondrial pathway in human leukemic K562 cells. Eur. J. Pharm. Sci. 2016, 81, 172-180. [CrossRef] [PubMed]

31. Kaisarevic, S.; Dakic, V.; Hrubik, J.; Glisic, B.; Lübcke-von Varel, U.; Pogrmic-Majkic, K.; Fa, S.; Teodorovic, I.; Brack, W.; Kovacevic, R. Differential expression of CYP1A1 and CYP1A2 genes in H4IIE rat hepatoma cells exposed to TCDD and PAHs. Environ. Toxicol. Pharmacol. 2015, 39, 358-368. [CrossRef]

32. Voelker, D.; Vess, C.; Tillmann, M.; Nagel, R.; Otto, G.W.; Geisler, R.; Schirmer, K.; Scholz, S. Differential gene expression as a toxicant-sensitive endpoint in zebrafish embryos and larvae. Aquat. Toxicol. 2007, 81, 355-364. [CrossRef]

33. Fu, Q.; Liu, S.; Wang, H.; Chen, S. Simultaneous determination of eight flavonoids in Polygonum aviculare L. by RP-HPLC-UV. J. Chin. Pharm. Sci. 2014, 23, 170-176. [CrossRef]

34. Smolarz, H.D. Flavonoid glycosides in nine Polygonum L. taxons. Acta Soc. Bot. Pol. 2002, 71, 29-33. [CrossRef]

35. Smolarz, H.D. Comparative study on the free flavonoid aglycones in herbs of different species of Polygonum L. Acta Pol. Pharm. 2002, 59, 145-148. [PubMed]

36. Cong, H.J.; Zhang, S.W.; Zhang, C.; Huang, Y.J.; Xuan, L.J. A novel dimeric procyanidin glucoside from Polygonum aviculare. Chin. Chem. Lett. 2012, 23, 820-822. [CrossRef]

37. Yunuskhodzhaeva, N.A.; Eshbakova, K.A.; Abdullabekova, V.N. Flavonoid composition of the herb Polygonum aviculare. Chem. Nat. Compd. 2010, 46, 803-804. [CrossRef]

38. Avula, B.; Joshi, V.C.; Wang, Y.H. Simultaneous Identification and Quantification of Anthraquinones, Polydatin, and Resveratrol in Polygonum multiflorum, Various Polygonum Species, and Dietary Supplements by Liquid Chromatography and Microscopic Study of Polygonum Species. J. AOAC Int. 2007, 90, 1532-1538. [CrossRef]

39. Kawasaki, M.; Kanomata, T.; Yoshitama, K. Flavonoids in the Leaves of Twenty-Eight Polygonaceous Plants. Bot. Mag. Shokubutsugaku-zasshi 1986, 99, 63-74. [CrossRef]

40. Al-Hazimi, H.M.A.; Haque, S.N. A new naphthoquinone from Polygonum aviculare. Nat. Prod. Lett. 2002, 16, 115-118. [CrossRef]

41. Kim, H.J.; Woo, E.R.; Park, H.A. Novel Lignan and Flavonoids from Polygonum aviculare. J. Nat. Prod. 1994, 57, 581-586. [CrossRef]

42. Nikolaeva, G.G.; Lavrent'Eva, M.V.; Nikolaeva, I.G. Phenolic compounds from several Polygonum species. Chem. Nat. Compd. 2009, 45, 735-736. [CrossRef]

43. Granica, S. Quantitative and qualitative investigations of pharmacopoeial plant material polygoni avicularis herba by UHPLCCAD and UHPLC-ESI-MS methods. Phytochem. Anal. 2015, 26, 374-382. [CrossRef] [PubMed]

44. Granica, S.; Piwowarski, J.P.; Popławska, M.; Jakubowska, M.; Borzym, J.; Kiss, A.K. Novel insight into qualitative standardization of Polygoni avicularis herba (Ph. Eur.). J. Pharm. Biomed. Anal. 2013, 72, 216-222. [CrossRef] [PubMed]

45. Granica, S.; Czerwińska, M.E.; Zyżyńska-Granica, B.; Kiss, A.K. Antioxidant and anti-inflammatory flavonol glu-curonides from Polygonum aviculare L. Fitoterapia 2013, 91, 180-188. [CrossRef] [PubMed]

46. Cai, Y.; Wu, L.; Lin, X.; Hu, X.; Wang, L. Phenolic profiles and screening of potential $\alpha$-glucosidase inhibitors from Polygonum aviculare L. leaves using ultra-filtration combined with HPLC-ESI-qTOF-MS/MS and molecular docking analysis. Ind. Crop. Prod. 2020, 154, 112673. [CrossRef]

47. Smolarz, H.D.; Budzianowski, J.; Bogucka-Kocka, A.; Kocki, J.; Mendyk, E. Flavonoid glucuronides with anti-leukaemic activity from Polygonum amphibium L. Phytochem. Anal. 2008, 19, 506-513. [CrossRef] [PubMed]

48. Ghazali, M.; Alfazari, M.; Al-Naqeb, G.; Krishnan Selvarajan, K.; Hazizul Hasan, M.; Adam, A. Apoptosis induction by Polygonum minus is related to antioxidant capacity, alterations in expression of apoptotic-related genes, and S-phase cell cycle arrest in HepG2 cell line. BioMed. Res. Int. 2014, 2014, 539607.

49. Hu, B.; An, H.M.; Shen, K.P.; Song, H.Y.; Deng, S. Polygonum cuspidatum extract induces anoikis in hepatocarcinoma cells associated with generation of reactive oxygen species and downregulation of focal adhesion kinase. Evid.-Based Compl. Alt. 2012, 2012, 607675. [CrossRef] [PubMed]

50. Raja, S.; Ramya, I.A. Comprehensive review on Polygonum glabrum. IJOP 2017, 8, 457-467.

51. Chiu, Y.J.; Chou, S.C.; Chiu, C.S.; Kao, C.P.; Wu, K.C.; Chen, C.J.; Tsai, J.C.; Peng, W.H. Hepatoprotective effect of the ethanol extract of Polygonum orientale on carbon tetrachloride-induced acute liver injury in mice. J. Food Drug Anal. 2017, 26, 369-379. [CrossRef] [PubMed]

52. Stark, G.R.; Taylor, W.R. Analyzing the G2/M checkpoint. In Checkpoint Controls and Cancer; Humana Press: Totowa, NJ, USA, 2004; pp. 51-82.

53. Lee, T.; Lau, T.; Ng, I. Doxorubicin-induced apoptosis and chemosensitivity in hepatoma cell lines. Cancer Chemother. Pharmacol. 2002, 49, 78-86. [CrossRef]

54. Shieh, D.E.; Chen, Y.Y.; Yen, M.H.; Chiang, L.C.; Lin, C.C. Emodin-induced apoptosis through p53-dependent pathway in human hepatoma cells. Life Sci. 2004, 74, 2279-2290. [CrossRef] 
55. Lee, B.H.; Huang, Y.Y.; Wu, S.C. Hepatoprotective activity of fresh Polygonum multiflorum against HepG2 hepatocarcinoma cell proliferation. J. Food Drug Anal. 2011, 19, 26-32.

56. Ow, Y.Y.; Stupans, I. Gallic acid and gallic acid derivatives: Effects on drug metabolizing enzymes. Curr. Drug Metab. 2003, 4, 241-248. [CrossRef]

57. Badhani, B.; Sharma, N.; Kakkar, R. Gallic acid: A versatile antioxidant with promising therapeutic and industrial applications. RSC Adv. 2015, 5, 27540-27557. [CrossRef]

58. Kim, S.R.; Lee, E.Y.; Kim, D.J.; Kim, H.J.; Park, H.R. Quercetin inhibits cell survival and metastatic ability via the EMT-mediated pathway in oral squamous cell carcinoma. Molecules 2020, 25, 757. [CrossRef] [PubMed]

59. Pinmai, K.; Chunlaratthanabhorn, S.; Ngamkitidechakul, C.; Soonthornchareon, N.; Hahnvajanawong, C. Synergistic growth inhibitory effects of Phyllanthus emblica and Terminalia bellerica extracts with conventional cytotoxic agents: Doxorubicin and cisplatin against human hepatocellular carcinoma and lung cancer cells. World J. Gastroenterol. 2008, 14, 1491. [CrossRef] [PubMed]

60. Gopalakrishnan, A.; Kong, A.N. Anticarcinogenesis by dietary phytochemicals: Cytoprotection by Nrf2 in normal cells and cytotoxicity by modulation of transcription factors NF-kB and AP-1 in abnormal cancer cells. Food Chem. Toxicol. 2008, 46, 1257-1270. [CrossRef] [PubMed]

61. Ramos, S. Cancer chemoprevention and chemotherapy: Dietary polyphenols and signalling pathways. Mol. Nutr. Food Res. 2008, 52, 507-526. [CrossRef] [PubMed]

62. Hybertson, B.M.; Gao, B.; Bose, S.K.; McCord, J.M. Oxidative stress in health and disease: The therapeutic potential of Nrf2 activation. Mol. Asp. Med. 2011, 32, 234-246. [CrossRef] [PubMed]

63. Wang, X.J.; Sun, Z.; Villeneuve, N.F.; Zhang, S.; Zhao, F.; Li, Y.; Chen, W.; Yi, X.; Zheng, W.; Wondrak, G.T.; et al. Nrf2 enhances resistance of cancer cells to chemotherapeutic drugs, the dark side of Nrf2. Carcinogenesis 2008, 29, 1235-1243. [CrossRef] [PubMed] 